\title{
THE INFLUENCE OF USING SHOPEEPAY AND SHOPEE PAYLATER FEATURES ON SHOPEE USER PURCHASING DECISIONS DURING THE COVID- 19
}

\author{
Sri Lestari*, Naniek Utami Handayani*, Manik Mahacandra* \\ Department of Industrial Engineering and Management, Diponegoro University \\ Jl. Prof. Soedarto, SH, Tembalang, Semarang, Indonesia
}

\begin{abstract}
A process of buying and selling products, information and services that is carried out electronically by utilizing a computer network is often known as E-commerce and providing ease of payment, namely by using the ShopeePay and Shopee PayLater features. This study aims to find out which independent variables are variables that can influence purchasing decisions for Shopee users and find out which factors are more dominant in influencing purchasing decisions for Shopee users on the use of Shopeepay and Shopee PayLater features. Moreover, the trend of consumer behavior in the future also can be explored from the Zscore. The research method used is the method of Discriminant Analysis. The data collection technique was carried out by surveying 55 respondents through questionnaires. From the equation formed, consumers' tendency to buy or not to make purchases through Shopee E-Commerce is determined by the Customer Satisfaction variable in the transaction. Furthermore, from the $\mathrm{Z}$ value, the group that does not make purchases $(0)$ has a $Z$ value $=0.214$, while the group that often makes purchases $(1)$ has a $Z=-0.207$ value. From the equation formed, consumers' tendency to buy or not to make purchases through Shopee E-Commerce is determined by the Customer Satisfaction variable in the transaction. Moreover, from the $Z$ value, the group that does not make purchases ( 0 ) has a $Z$ value $=0.214$, while the group that often makes purchases (1) has a $Z=-0.207$ value. From the equation formed, consumers' tendency to buy or not to make purchases through Shopee E-Commerce is determined by the Customer Satisfaction variable in the transaction. Furthermore, from the $\mathrm{Z}$ value, the group that does not make purchases (0) has a $\mathrm{Z}$ value $=0.214$, while the group that often makes purchases (1) has a $\mathrm{Z}=-0.207$ value .
\end{abstract}

Keywords: discriminant analysis; Shopeepay; Shopee PayLater; customer satisfaction; purchasing decisions

\section{Introduction}

In its development, the internet is currently not only a medium of information and communication, but the internet can increase one's income in the economy. The internet has changed the flow of trade in the business world to be completely digital. Today's business mechanisms are built into networked communities. Slowly but surely, internet penetration has changed consumer buying behavior in meeting their needs (Pratiwi, 2013). Online shopping is currently very prevalent in modern society. They were starting from teenagers to the elderly who understand the use of smartphones. For some people, online shopping is a need that must be met for their life as a consumer.

The number of the attractive image offers affordable prices on the online shop makes people interested in shopping and the desire to make themselves like the one in the picture. In online shopping, customers do not need to meet the seller (face to face), but only with a smartphone and an internet connection can customers make transactions comfortably. A process of buying and

\footnotetext{
*Penulis Korespondensi.

E-Mail: srilestari997@students.undip.ac.id, naniekh@live.undip.ac.id, manik.mahachandra@gmail.com
}

selling products, information and services that is carried out electronically by utilizing a computer network is often known as e-commerce. One of the networks used is the internet (Handayani et al., 2013). Shopping has become necessary for every human being; the high level of shopping in society has created an innovation in shopping, namely an online shop or online shopping.

The spread of the coronavirus is increasingly widespread in Indonesia. According to data on the distribution of Covid - 19 on April 1, 2021, the number of cases positive for the Covid - 19 virus was 1,517,854 people (covid.go.id, April 2021). With the increasing number of Covid-19 positives, the government has decided to carry out all activities at home, such as studying, working, and worshiping. In addition, so far, all regions have implemented large-scale social restrictions to break the rope of the spread of Covid-19. It, of course, will further limit community activities outside the home. Usually, we can shop directly at the market or supermarket. Nowadays, people choose to shop online because it is easier, faster, has many choices, and most importantly, does not have to hang out with large crowds so that this opportunity is not wasted by e-commerce or online shops. Because with an online shop, they can meet household needs easily and quickly, so they still follow the applicable rules. Without having to go outside the house, the goods will arrive safely and securely. By 
providing convenience in shopping, the government hopes to help government programs for "just at home" and ease when making payment transactions by limiting activities outside the home. One of the ways is to use Electronic Money or Digital Money.

Electronic money is a payment instrument that fulfills elements such as being issued based on the value of money deposited in advance by the holder to the issuer, the value of money stored electronically in a medium such as a server or chip, used as a means of payment to merchants who are not the issuer of the electronic money. Moreover, the value of electronic money that has been deposited by the holder and managed by the issuer. Electronic money itself aims to make it easier for humans to carry out all kinds of economic transactions in their lives, especially for micro-scale transactions. Publishers or providers of electronic money also vary, such as emoney which is a product of Mandiri Bank, Brizzi which is a product of BRI Bank, tap cash which is a product of BNI Bank, Flazz which is a product of BCA Bank, also Shopeepay and Shopee PayLater which are products of Shopee, Dana, OVO, and others, so that they can make it easier and help the government to comply with the rules for "stay at home" during this Covid - 19 pandemic.

Shopee is mobile application-based e-commerce that is currently significantly developing in Indonesia. Shopee was founded in 2009 by Forrest $\mathrm{Li}$ and was first launched in Singapore in 2015. Now, Chris Feng leads Shopee. The development of online shopping such as Shopee is now increasingly crowded with various products it offers ranging from men's and women's fashion, food and beverages, furniture even electronics. Shopee not only makes shopping easy, but Shopee also provides convenience in making transactions when shopping, one of which is the payment methods using electronic money or digital money such as ShopeePay and Shopee PayLater. With ShopeePay, buyers will get accessible shipping facilities. However, sometimes they are subject to a minimum shopping requirement and various other benefits such as discounts or cashback in ShopeePay points. ShopeePay, which is a payment system owned by Shopee's affiliate, PT. AirPay International Indonesia, so that it is an advantage in this competition. ShopeePay Later is like OVO PayLater, namely instant loans provided by Shopee users who have already received this service. Interestingly, on Shopee PayLater, Shopee users can enjoy installments with $0 \%$ interest. A loan Facility is any financial facility in the form of a loan in the rupiah currency provided by the lender to Shopee users as loan recipients using the Shopee PayLater service with the value and terms set out in the related loan agreement.

Based on the background of the problems seen, several problem formulations can be taken. First, the independent variable will be consisting of Feature Knowledge, Customer Satisfaction, and Risk of Use, which can determine the purchasing decisions of Shopee users. Customer satisfaction is customer satisfaction after comparing the services or products received by what is expected. Assess customer satisfaction and increase consumer expectations so that they can become loyal repeat customers. Customer satisfaction is also one of the keys to creating customer loyalty because satisfied customers will be loyal (Aryani, 2010). Consumer satisfaction is obtained from how they respond to a product or an electronic payment feature, between consumer perceptions and preferences with reality they received. Moreover, the risk of using e-money is lost and can be used by other parties, the sip of e-money because the principle is like cash which if lost cannot be claimed from is the same issuer (Bank of Indonesia, 2019). The risk is due to the user's lack of understanding in using electronic money, such as the user is not aware that the electronic money used is affixed twice to the reader for the same transaction so that the value of electronic money is reduced by more significant than the value of the transaction. However, the risk of using Shopeepay comes in the disbursement process. An account has a long-time ranging buying decision from 2-3 days, so it is timeconsuming for someone who suddenly needs cash funds. Whilst Shopee PayLater cannot be withdrawn. In general, online loans are in the form of cash, which will be transferred to the account if approved. The services provided by Shopee are not like this and are different, especially for credit for product shopping. Purchasing decisions are thoughts where individuals evaluate various options and choose a product from the many choices. Purchasing decisions are stages that occur in the buyer's decision-making process where consumers will buy the products (Kotler et al., 2014). Finally, we can find out which variables are the more dominant factors that can influence the purchasing decisions of Shopee users.

\section{Methods}

The population in this case were all Shopee users who had made online purchase transactions during the pandemic. In this study, the authors used the Quota Sampling technique because, considering the massive population of Shopee users, 55 respondents were sufficient.

\section{a. Data}

This research requires primary data obtained directly by the author through the data collection method used. The primary data used in this study is filling out a questionnaire made and addressed to Shopee ECommerce users for data needs on Discriminant Analysis. Moreover, secondary data were obtained from journals and books related to this study for reference literature studies.

\section{b. Statistical Test}

For analysis purposes, the Discriminant Analysis Model is used. The model of discriminant analysis is an equation that shows a linear combination of various independent variables, i.e.:

$$
\begin{aligned}
& D_{i}=b_{0}+b_{1} . x_{1}+b_{2} . x_{2}+b_{3} . x_{3} \\
& \text { Where : } \\
& D_{i}=\text { Discriminant Score } \\
& b=\text { Discriminant Coefficient } \\
& x=\text { Independent Variable } \\
& x_{1}=\text { Feature Knowledge }
\end{aligned}
$$


Table 1. Feature Knowledge

\begin{tabular}{cll}
\hline No. & \multicolumn{1}{c}{ Indicator } & Statement in the Questionnaire \\
\hline 1 & ShopeePay & Statement 1 \\
2 & Shopee PayLater & Statement 2 \\
\hline
\end{tabular}

Table 2. Customer Satisfaction

\begin{tabular}{cll}
\hline No. & \multicolumn{1}{c}{ Indicator } & Statement in the Questionnaire \\
\hline 1 & Convenience in Process Payment & Statement 3,4 \\
2 & Speed Up Transactions & Statement 5,6 \\
\hline \multicolumn{3}{c}{ Table 3. Risk of Use } \\
\hline No. & \multicolumn{1}{c}{ Indicator } & Statement in the Questionnaire \\
\hline 1 & Difficulty Disbursement of Funds & Statement 7 \\
2 & During Installment & Statement 8 \\
\hline
\end{tabular}

Table 4. Buying Decision

\begin{tabular}{cll}
\hline No. & \multicolumn{1}{c}{ Indicator } & \multicolumn{1}{c}{ Statement in the Questionnaire } \\
\hline 1 & Feature Bonus & Statement 9,11 \\
2 & Fast, Safe and Practical & Statement 10,12 \\
\hline
\end{tabular}

Table 5. Respondent Gender

\begin{tabular}{lcc}
\hline \multicolumn{1}{c}{ Gender } & Amount & Percentage (\%) \\
\hline Man & 24 & 43.6 \\
Women & 31 & 56.4 \\
Total & 55 & 100 \\
\hline
\end{tabular}

Source: Questionnaire Processing Results

$\mathrm{x}_{2}=$ Customer satisfaction

$\mathrm{x}_{3}=$ User Risk

\section{c. Data Collection}

In obtaining data sources, both primary and secondary data, the authors use several methods to collect these data. The following is a questionnaire data collection method used, among others. The questionnaire is a method of collecting data directly by asking the respondents a list of questions. The questionnaire was addressed to all Shopee E-Commerce users, which aims to determine the extent of users' knowledge of the features contained in Shopee, to find out the extent of customer satisfaction from various aspects of these features, the risks associated with using these features, and how Shopee users purchase decisions. This questionnaire is distributed to all Shopee E-Commerce users. The questionnaire assessment method uses a Likert scale, namely by weighting each question item on a scale of 1 to 5 from strongly disagree to agree strongly.

Score

1) (Strongly Disagree/ SD)/ (Strongly Don't Know/ SDK)

2) (Disagree/ D)/ (Don't Know/ DK)

3) (Don't agree/ DA)/ (Don't know/ DK

4) $($ Agree/ A)/ (Know/ K)

5) (Strongly Agree/ SA)/ (Very Knowing/VK)

The following are the grid statements in measuring feature knowledge, customer satisfaction, the risk of use, and purchasing decisions, consecutively in Table 1 to 4.

\section{Results and Discussion \\ a. Demographic Results}

This research was conducted by distributing questionnaires to 55 respondents as active users of Shopee's ECommerce and having made purchases in ECommerce, with the following characteristics:

\section{Gender of Respondent}

Table 5 shows the results of the analysis regarding the gender of the respondents in this study. From the Table 5, most of the respondents in this study were 31 people, or as much as $56.4 \%$ were men. It means that currently, men are more consumptive than women.

\section{Age of Respondents}

The results of the analysis regarding the age of the respondents can be seen in Table 6. Researchers only examined respondents aged 15 years to more than 35 years. The Table 6 shows that most respondents who make transactions on E-commerce Shopee are at the age of $15-25$ years, which is $57.3 \%$. It shows that respondents generally do not have significant responsibilities at this age but already have income, and there is always a desire to try something new. That is why they make many transactions.

\section{Respondents Income}

From the results of the analysis regarding respondents' income, we can see in Table 7. From the table above, most respondents' income who transact through online media is at the level > IDR 3,000,000, - 
Table 6. Respondent Age

\begin{tabular}{lcc}
\hline \multicolumn{1}{c}{ Age } & Amount & Percentage (\%) \\
\hline 15 - 25 years & 26 & 57.3 \\
26 - 30 years & 8 & 14.5 \\
>35 years & 21 & 38.2 \\
Total & 55 & 100 \\
\hline
\end{tabular}

Source: Questionnaire Processing Results

Table 7. Respondent Income

\begin{tabular}{lcc}
\hline \multicolumn{1}{c}{ Income } & Amount & Percentage (\%) \\
\hline < IDR 500,000 & 13 & 23.6 \\
IDR 500,001 - IDR 1,000,000 & 8 & 14.5 \\
IDR 1,000,001 - IDR 3,000,000 & 11 & 20 \\
>IDR 3,000,000 & 23 & 41.9 \\
Total & 55 & 100 \\
\hline
\end{tabular}

Source: Questionnaire Processing Results

Table 8. Reliability Test

\begin{tabular}{cc}
\hline Cornbach's Alpha & N of Items \\
\hline 0.732 & 13 \\
\hline Source: Results of SPSS 25 Discriminant Analysis
\end{tabular}

Table 9. Canonical Discriminant Function

\begin{tabular}{lc}
\hline & Function 1 \\
\hline Feature Knowledge & -0.611 \\
Customer Satisfaction & 1.350 \\
Risk of Use & 0.876 \\
(Constant) & -5.932 \\
\hline
\end{tabular}

Unstandardized Coefficients

Source: Results of SPSS 25 Discriminant Analysis

Table 10. Functions at Group Centroids

\begin{tabular}{lcc}
\hline \multicolumn{1}{c}{ Buying Decision } & Function 1 \\
\hline Don't Buy & 0.214 \\
Buy & -0.207 \\
\hline
\end{tabular}

Source: Results of SPSS 25 Discriminant Analysis

23 respondents then followed by the level < IDR $500,000,-$ as many as 13 respondents.

\section{b. Validity Test and Reability Test}

In the table of the results of the validity test conducted on 55 respondents, the questionnaire consisting of 12 questions with each score is valid, except questions 7 and 8, which have a value of $R$ is less than $R$ table. With all the positively correlated questions or more than 0.266 , which is more than $75 \%$ of the total question items, the conclusion is that this questionnaire has a valid instrument. Moreover, the reliability test result was a Cronbach's alpha value of more than 0.60 . It shows that all the questions contained in the questionnaire are reliable.

\section{c. Discriminant Analysis}

Discriminant analysis can be used to see how strong the use of factors or variables is in making purchasing decisions, namely by forming a model of the variables that will distinguish consumers' tendencies in making purchase transactions through online media. The following Table 9 displays the discriminant function, which is entered into the discriminant equation. From the test result, the form of the discriminant function is as follows:

$$
\begin{gathered}
\mathrm{Z} \text { Score }=-5,932+1,350(\text { Satisfaction })+0.876 \\
(\text { Risk })
\end{gathered}
$$

Here it can be seen from the equation that the Customer Satisfaction variable determines the tendency of consumers to buy or not to make purchases through Shopee E-Commerce in the transaction. In this study, there are two types of consumers, which are called Two Group Discriminants, which will separate consumers who buy or do not buy through Shopee's E-Commerce through the Negative Centroid Group and Positive Centroid Group as shown Table 10. From the Table 10, the group that does not make purchases $(0)$ has a $Z$ value $=0.214$, while the group that often makes purchases (1) has a $\mathrm{Z}$ value $=-0.207$

The tendency of consumers to make purchasing decisions through the online media of E-Commerce Shopee is based on 55 respondents. The discriminant function is made, then the researcher classifies it to determine how far the accuracy is or what percentage of 
Table 11. Classification Results

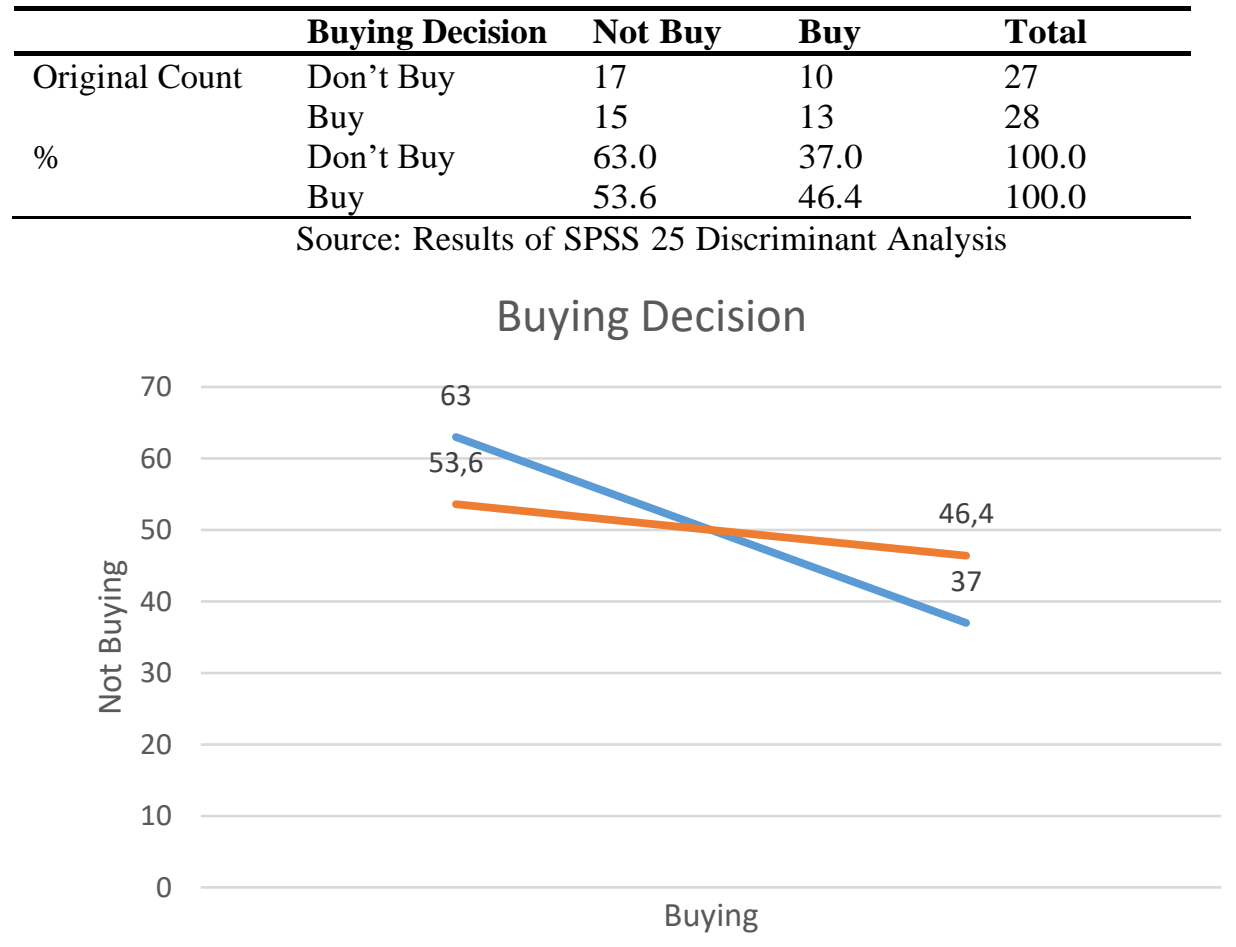

Figure 1. Purchase Decision

Table 12. Wilks' Lambda

\begin{tabular}{ccccc}
\hline Test of Function(s) & Wilks' Lambda & Chi-square & df & Sig. \\
\hline 1 & 0.956 & 2.315 & 3 & 0.510 \\
\hline \multicolumn{4}{c}{ Source: Results of SPSS 25 Discriminant Analysis } \\
\end{tabular}

misclassification occurs in the classification process, then in Table 11.

The Table 11 shows that in the original section, those who in the initial data belongs to the Do Not Buy group makes purchases as many as 27 people, with the discriminant model, it turns out that ten people move into the Buying group to make purchases. Compared to consumers who buy make purchases as many as 28 people, 13 people moved groups to rarely made purchases.

When viewed from the movement of consumer behavior trends in the future, The movement of consumers who initially rarely made purchases as many as 27 people who moved 17 people to the Not buying group, this means that in the future consumer behavior Rarely does consumers increase more than $50 \%$ of the group who will still make purchases due to several variable factors of use and customer satisfaction.

\section{d. Graphical Results}

Figure 1 shows that the results of the purchase decision after a discriminant analysis using SPSS 25 software shows that in the original part, those who in the initial data belongs to the Do Not Buy group purchase as many as 27 people, with the discriminant model it turns out that those who move into the Buying group to make purchases of 10 people with a percentage of $63 \%$ and
$27 \%$. Meanwhile, of the consumers who made purchases as many as 28 people, 13 people moved groups to rarely make purchases with a percentage of $53.6 \%$ and $46.4 \%$.

\section{e. Proposed Improvement}

Based on Table 12 (Wilks 'Lambda), the significance value was 0.510 , which is more than 0.05 . It means that the resulting discriminant equation does not involve independent variables. In this study, the variables of Feature Knowledge, Customer Satisfaction, and Risk of Use are variables that have not been able to differentiate in purchasing decision making, so it is hoped that further researchers can reconsider ratios or other indicators as a tool to improve purchasing decisions on the use of Shopeepay features. Furthermore, Shopee PayLater because will make transactions easier during a pandemic like today.

\section{f. Validation}

Based on Table 13, we can see that the data used is valid. Due to missing data, there were no ranges between groups, and no differentiating variables were lost.

\section{g. Discussion}

A process of buying and selling products, information and services that is carried out electronically 
Table 13. Analysis Case Processing Summary

\begin{tabular}{llcc}
\hline Unweighted Cases & $\mathbf{N}$ & Percent \\
\hline Valid & & 55 & 100.0 \\
Excluded & Missing or out-of-range group codes & 0 & 0 \\
& At least one missing discriminating variable & 0 & 0 \\
& Both missing or out of range group codes and & 0 & 0 \\
& at least one missing discriminating variable & & \\
Total & Total & 0 & 0 \\
& & 55 & 100.0 \\
\hline
\end{tabular}

Source: Results of SPSS 25 Discriminant Analysis

by utilizing a computer network is often known as Ecommerce and providing ease of payment. Shopping has become a necessity for every human being, the high level of shopping in the community, then innovation in shopping is created, namely an online shop or shopping online. The development of online shopping such as Shopee, which is now increasingly crowded with various products it offers, ranging from men's and women's fashion, food and beverages, furniture, and even electronic goods. The increasing number of services for online buying and selling facilities can cause changes in shopping patterns for people who initially shop conventionally or traditionally until now to switch to modern ways both online and which are very practical and make it easier to choose their goods anywhere and anytime when needed. And during a pandemic like this we are given the convenience of shopping online and given convenience when making payment transactions by limiting activities outside the home, one way is to use Electronic Money or Digital Money such as ShopeePay and Shopee PayLater.

There are many advantages to using digital money such as ShopeePay and Shopee PayLater, including being able to make it easier and faster in various kinds of transactions, and no longer accepting change in goods (such as candy or chocolate) due to traders not having small change or small change. However, there are not a few risks that will be faced by ShopeePay and Shopee PayLater users, including money that is difficult to withdraw, is limited in nature which can only be used on the Shopee application, and interest is only $1 \%$ but a fine of $5 \%$.

Based on the results of data analysis conducted on 55 respondents who have filled out the questionnaires that have been distributed, most of them are men aged 15-25 years with an average income of > IDR 3,000,000. From the results of the validity test conducted on 55 respondents, the questionnaire consisting of 12 questions with each score is valid, except questions 7 and 8 , which have a value of $\mathrm{R}$ is less than $\mathrm{R}$ table. With all the positively correlated questions or more than 0.266 , which is more than $75 \%$ of the total question items, the conclusion is that this questionnaire has a valid instrument. Moreover, the reliability test result was a Cronbach's alpha value of more than 0.60. It shows that all the questions contained in the questionnaire are reliable. Discriminant analysis can be used to see how strong the use of factors or variables is in making purchasing decisions, namely by forming a model of the variables that will distinguish consumers' tendencies in making purchase transactions through online media. And the discriminant function can be seen that the Customer Satisfaction variable determines the tendency of consumers to buy or not to make purchases through Shopee E-Commerce in the transaction by looking at the Centroid Function Table, the group that does not make a purchase (0) has a $\mathrm{Z}$ value $=0.214$, while the who frequently make purchases (1) have a value of $Z=-0.207$. The tendency of consumers to make purchasing decisions through Shopee's online E-Commerce media is based on 55 respondents. The discriminant function is created, then the researcher classifies it to find out how far the accuracy or percentage of classification errors occur in the classification process, it appears that in the initial data that entered the Don't Buy group made purchases of 27 people, with the discriminant model it turned out that ten people entered the Buy group. to make a purchase. Compared to consumers who bought as many as 28 people, 13 people changed groups to make purchases less frequently. When viewed from the movement of consumer behavior trends in the future, the movement of consumers who initially rarely made purchases as many as 27 people who moved 17 people to the Not buying group this will have a further impact on consumer behavior Rarely consumers increased by more than $50 \%$ of the group that would still make purchases due to several factors of use and customer satisfaction.

So, it can be concluded in this study that the variables of Feature Knowledge, Customer Satisfaction, and Usage Risk are variables that have not been able to differentiate in making purchasing decisions. Because it is known that this variable has an F value above Sig. 0.05 and the matrix structure explains the close relationship between each independent variable, namely Feature Knowledge, Customer Satisfaction, and Usage Risk on the discriminant function taken from several previous studies, namely I'in. EM and Orland JE, (2013) concerning Analysis of Consumer Purchase Decisions Through Online Media (E-Marketing); Siti Lam'ah Nasution, et al (2020) regarding the Effect of Product Quality, Brand Image, and Price on Purchase Decisions at Shopee E-Commerce; Istiqomah, et al. (2019) on Analysis of the Effect of Trust, Advertising, and Prices for Purchase Decisions at Shopee E-Commerce; Istiqomah, et al. (2019) regarding Analysis of the Effect of Trust, Advertising, and Risk Perception on Purchase Decisions at Shopee. 


\section{Conclusion}

This study aims to find out which independent variables can influence purchasing decisions for ShopeePay users and Shopee PayLater features and find out which variables are the more dominant factors that can influence purchasing decisions for Shopee users. The data analysis method used is the Discriminant Analysis Method to answer how variables that can influence purchasing decisions for users using Shopeepay and Shopee PayLater features and variables, which are more dominant factors in purchasing decisions of Shopeepay and Shopee PayLater users. There are three variables used, including Feature Knowledge, Customer Satisfaction, and Risk of Use.

In this study, Feature Knowledge, Customer Satisfaction, and Risk of Use variables are variables that have not been able to differentiate in purchasing decision making. Because it is known that this variable has an $\mathrm{F}$ value above Sig. 0.05. The matrix structure explains the closeness of the relationship between each independent variable, namely Feature Knowledge, Customer Satisfaction, and Risk of Use to the discriminant function. The Use Risk variable has the most substantial relationship with the discriminant function, then followed by the Customer Satisfaction and Feature Knowledge variables.

\section{Reference}

Adhinagari, AH. (2018). Effect of Perceptions of Benefits, Perceptions of Ease, Trust and Perceptions of Risk on Perceptions of E-money Use. Thesis. Yogyakarta: Indonesian Islamic University.

Aksami, N. M. D, and Jember, I. M. (2019). Interest Analysis of Using E-Money Services in Society of Denpasar City. E-Journal EP Udayana University, 8(9), $2.439-2.470$.

Aryani, Dwi. (2010). The Effect of Service Quality on Customer Satisfaction in Forming Customer Loyalty. Journal of Administrative and Organizational Sciences, 17 (2), 114 - 126.
Brenda, Kienan. (2001). Small Business Solutions Ecommerce. Gramedia Press.

DeLone, W.H., and McLean, E.R. (2004). Measuring ECommerce Success. International Journal of Electronic Commerce, 9(2), 31-47.

DeLone, W.H., \& McLean, E.R. (2016). Information System Success Measurement. Foundation and Trends in Information Systems, 2(1), 1 - 116.

Fandy, Tjiptono. (2007). Marketing Strategy, $5^{\text {th }}$ Edition. Andi Press.

Ghozali, I., and Chariri, A. (2007). Accounting Theory. Semarang: Diponegoro University Publishing Agency.

Handayani, SP, and Purnama, BE. (2013). Making ECommerce Website at Java Trend Distro. Research Seminar National Informatics and Computers, 2(1), 18-24.

Nasution, S.L, Limbong, C.H, and Nasution, D.A.R. (2020). Influence on Product Quality, Brand Image, Trust, Easy, and Price on Purchase Decisions on The Ecommerce Shopee. Journal of Ecobisma, 7(1), 43 - 53.

Nawawi, H. (2015). Social Research Methods. Gajah Mada University Press.

Pratiwi, HD. (2013). Effect of Company Reputation and Website Quality on Consumer Confidence Level in Online Transaction. Academia.

Rahmatika, Ula. (2019). Factors Affecting Intention to Use Electronic Money: TAM - TPB Model Integration with Perceived Risk. Nominal Journal, 3(2), 274 - 284.

Wafa, Ah. (2020). Review of Sharia Economic Law on Shopeepay Later. Journal of Sharia Economic Law, 4(1), 17 - 30.

Yin, RK. (2014). Case Study Design \& Methods. Rajawali Pers.

Zulqarnain, S. (2017). Effect of Promotional Attractiveness, Perceptions of Ease, and Perceptions of Benefit on Interests Using Emoney. Thesis. Yogyakarta: Sunan Kalijaga State Islamic University. 